\title{
Viewpoints
}

\section{How the Barrel Cortex Became a Working Model for Developmental Plasticity: A Historical Perspective}

\author{
${ }^{-}$Reha S. Erzurumlu ${ }^{1}$ and ${ }^{\circledR}$ Patricia Gaspar ${ }^{2}$ \\ ${ }^{1}$ Department of Anatomy and Neurobiology, University of Maryland School of Medicine, Baltimore, Maryland 21201, and ${ }^{2}$ Institut National de la \\ Santé et de la Recherche Médicale, Paris Brain Institute, Sorbonne Universités, Paris, France 75013
}

For half a century now, the barrel cortex of common laboratory rodents has been an exceptionally useful model for studying the formation of topographically organized maps, neural patterning, and plasticity, both in development and in maturity. We present a historical perspective on how barrels were discovered, and how thereafter, they became a workhorse for developmental neuroscientists and for studies on brain plasticity and activity-dependent modeling of brain circuits. What is particularly remarkable about this sensory system is a cellular patterning that is induced by signals derived from the sensory receptors surrounding the snout whiskers and transmitted centrally to the brainstem (barrelettes), the thalamus (barreloids), and the neocortex (barrels). Injury to the sensory receptors shortly after birth leads to predictable pattern alterations at all levels of the system. Mouse genetics have increased our understanding of how barrels are constructed and revealed the interplay of the molecular programs that direct axon growth and cell specification, with activity-dependent mechanisms. There is an ever-rising interest in this sensory system as a neurobiological model to study development of somatotopy, patterning, and plasticity at both the morphologic and physiological levels. This article is part of a group of articles commemorating the 50th anniversary of the Society for Neuroscience.

\begin{abstract}
Milestones in barrel cortex development and plasticity:
discovery and coining the term "barrels"

The Society for Neuroscience was founded by Ralph Waldo Gerard in 1969, and the first meeting of the Society for Neuroscience gathered in Washington, DC in 1971. Coincidentally, the term "barrels" was coined in 1969, not far from Washington, DC by Thomas Woolsey, a medical student under the supervision of Hendrik Van der Loos at the Johns Hopkins University in Baltimore. Early cytoarchitectonic studies had already noted unusual clusters of neurons in layer 4 in the lateral cortex of rodents (de Nó, 1922; Rose, 1929), but the functional correlate of this anatomic organization was unclear and was wrongly attributed to the auditory cortex. It was Thomas Woolsey who made the observation that the whiskers on the snout of mice are represented by a patterned array of cylindrical neural aggregates in the somatosensory cortex. Using Nissl and Golgi staining, Woolsey and Van der Loos described the clustering of layer 4 neurons around a central, cellsparse region (named the hollow) that was most clearly visible in thick brain sections cut tangential to the cortical surface. They further demonstrated a remarkable, one-to-one correspondence between the layout of the barrels with those of the large mystacial vibrissae in the whisker pad. This landmark paper was published in
\end{abstract}

\footnotetext{
Received Mar. 25, 2020; revised June 22, 2020; accepted June 24, 2020.

This work was supported by National Institutes of Health/National Institute of Neurological Disorders and Stroke NS 084818, NS092216, and NS092216S1 to R.S.E., and Agence Nationale de la Recherche ANR-110004-02, ANR-15-0179, and ANR-16-0162, National de la Santé et de la Recherche Médicale, and Université Pierre et Marie Curie to P.G. We thank all our past, present, and future colleagues caring about the barrels (or carrying barrels) and apologize for not citing all the important work they contributed to the field.

The authors declare no competing financial interests.

Correspondence should be addressed to Reha S. Erzurumlu at rerzurumlu@som.umaryland.edu.

https://doi.org/10.1523/JNEUROSCI.0582-20.2020

Copyright $\odot 2020$ the authors
}

1970 in the then leading neuroscience journal, Brain Research. To give a sense of the excitement of this discovery, we include here excerpts from Tom Woolsey's (2016) review of the Woolsey and Van der Loos (1970) paper:

"In the summer of 1965, before entry in medical school at The Johns Hopkins, I worked in the Laboratory of Neurophysiology mapping sensory evoked potentials in the cerebral cortex of mice. This was a suggestion (assignment?) from my father [Clinton Woolsey] who had published studies of cortical evoked potential maps of rats in the late '40s (Woolsey, 1952)... I noticed that, unlike the Nissl stained sections of the human brains ... the sections of mouse brains had odd patterns of layer IV neurons in the somatosensory cortex. The region with patterns corresponded directly with the region that responded to stimulation of the facial whiskers- vibrissae- on the contralateral face.... I published an article on cortical localization of sensory functions in mouse (Woolsey, 1967).... I approached a then Assistant Professor of Anatomy who had taught neuroanatomy to us in our first year... Hendrik Van der Loos, MD, PhD (Molliver et al., 1994). From his lectures we learned that he had developed a staining method combining Golgi and Nissl staining. I thought this would be excellent for understanding organization of cell clusters in the 'whisker' cortex... In the Van der Loos laboratory, I learned and used the technique for embedding tissues in celloidin for slicing thicker sections on sliding microtomes. This was an obvious advantage for accurately slicing mouse brains tangential to the right brain surface location to visualize the cytoarchitecture of the whisker cortex in layer IV. 
The first Nissl stained slides showed the answer! Rings of neurons arranged in 5 rows mirroring the pattern of whiskers on the contralateral face and in layer IV of the cortex activated by whisker stimulation were obvious. In three dimensions they resembled cylinders tapered at the junctions with layers III above and V below. I named these structures barrels. The larger whiskers matched what I termed the posterior medial barrel sub-field (PMBSF) of the mouse somatosensory cortex (SmI) ... I put together the collages of photomicrographs and images of the tangential sections... In the spring of 1969, I wrote the manuscript and completed the graphics. In discussion with Van der Loos, he asked why I had added his name as author.... I pointed out the science had been done largely in his laboratory and this was appropriate... We submitted the article to Brain Research in the summer of $1969 . .$. We both were astounded to receive a letter from Professor Konrad Akert, the founder and chief editor of Brain Research, dated 2 weeks after the manuscript arrived in Zurich,... accepting the paper without any changes."

Following this pioneer paper, Van der Loos and Woolsey (1973), tested the hypothesis that signals derived from the whiskers informed barrel cortex development. The first landmark experiment was a cauterization of whisker rows in newborn mice followed by anatomic investigation of the barrel field layout several weeks later. The striking result was that lesions performed during the first few days of life prevented the formation of the corresponding barrel structures. Frank Rice, a graduate student of Van der Loos at the time, remembers this period as follows (personal communication):

"I began my PhD studies in the Department of Anatomy at Johns Hopkins Medical School in 1969 where Hendrik [Van der Loos] was on the faculty I think as an Associate Professor. I remember his promotion to Professor while I was there.... I fell in love with the Neuroanatomy Course taught almost entirely by Hendrik, which began in December 1969 ... we hit it off very well. I believe Tom [Woolsey] was in his last year of med school in 69$70 \ldots$ That was right at the time of the first publication and when the first whisker cauterization study was in progress.... Tom's father earned renown for the physiological mapping showing the detailed fundamental principle of somatotopic organization of the cortex in several species.... So, Tom followed in his father's footsteps. He mapped the mouse cortex in the physiology department as Summer research project. I am pretty sure that it was Tom who knew of the cytoarchtectonic studies of Rose from the 1920s ... deduced from sensory deficits in stroke patients. Tom recognized that those structures were physiologically located in somatosensory cortex. So, he worked with Hendrik to learn the celloidin technique where they gradually changed the cutting angle to being parallel to the cortical surfaces where the 'barrel' pattern representing the whiskers became evident. So that was pretty much Tom's work. Hendrik came up with the whisker cauterization study, which was entirely done by him and his wife Nolette. So, I was there when the sections were first coming out with the excitement of the missing rows of barrels, which led to the question of whether the barrels developed before or after the neonatal cauterizations, which became my thesis project."

The above-referred studies started the "whisker-barrel" research. Shortly after these publications, Woolsey and Van der Loos parted ways and pursued productive "barrel" research in their own respective laboratories. They made many other important contributions to the field, including naming the whiskerrelated cellular aggregates in the thalamus "barreloids" (Van der Loos, 1976) and those in the brainstem "barrelettes" (Ma and Woolsey, 1984).

\section{How the barrel cortex became a developmental model}

As a PhD student of Hendrik Van der Loos, Frank Rice followed him to Lausanne to finish his dissertation work. There, they set up an entire laboratory devoted to the understanding of barrel development, including studies of how genetic variations of the whisker implantation or function affected barrel organization. Using simple histologic stains (Nissl), Rice and Van der Loos showed that "the onset of barrel formation coincides with the moment after which injury to the pertinent somatosensory periphery no longer causes profound alterations in barrel morphology" (Rice and Van der Loos, 1977). Using comparative "evo-devo" strategies, they also showed that barrel-like somatosensory cortical patterning is present in most rodents that whisk (hamster, mouse, rat, and gerbil) while it is sparse or absent in species that minimally or never whisk (guinea pig, rabbit, and cat) (Rice, 1985a,b; Rice et al., 1985). These experiments indicated that the peripheral sensory receptors and their function were important drivers of anatomic organization, inspiring further studies on how the innervation to vibrissal follicle-sinus complexes develops during embryonic life (Fig. 1) (Rice et al., 1997; Cronk et al., 2002; Ebara et al., 2002).

\section{Not just neurons, axon terminals too replicate the whisker patterns}

Around the same time of the initial barrel papers, Herbert Killackey, a postdoctoral fellow with Ford Ebner, was studying thalamocortical (TC) projections in the opossum (Killackey and Ebner, 1972, 1973). Enthused by the mouse barrel cortex, he used the method of the time, silver impregnation of degenerating axons, and demonstrated a whisker-related discontinuous pattern of TC axons in the SI cortex of rats (Killackey, 1973). Killackey started the third pioneering laboratory in barrel research as a new Assistant Professor at the University of California, Irvine (Killackey and Leshin, 1975). One of us (Erzurumlu) had doctoral training (1977-1981) with Herb Killackey, and worked on the connections of the brainstem trigeminal nuclei and topographic order in the trigeminal nerve and ganglion (Erzurumlu and Killackey, 1979, 1980, 1982a,b, 1983).

\section{Emergence of new markers for barrel development}

Before immunocytochemistry (or genetic labeling) became prevalent, enzymatic histochemistry provided useful tools to visualize sensory maps, often with primary studies in the visual system (which was the hot topic in neuroscience at the time) and followup studies in the barrel cortex. In one such line of work, Margaret Wong-Riley showed that mitochondrial enzyme, cytochrome oxidase ( $\mathrm{CO}$ ) histochemistry could be used reliably to visualize patterns along the visual pathway and following sensory deprivation (Wong-Riley et al., 1978; Wong-Riley, 1979). This 


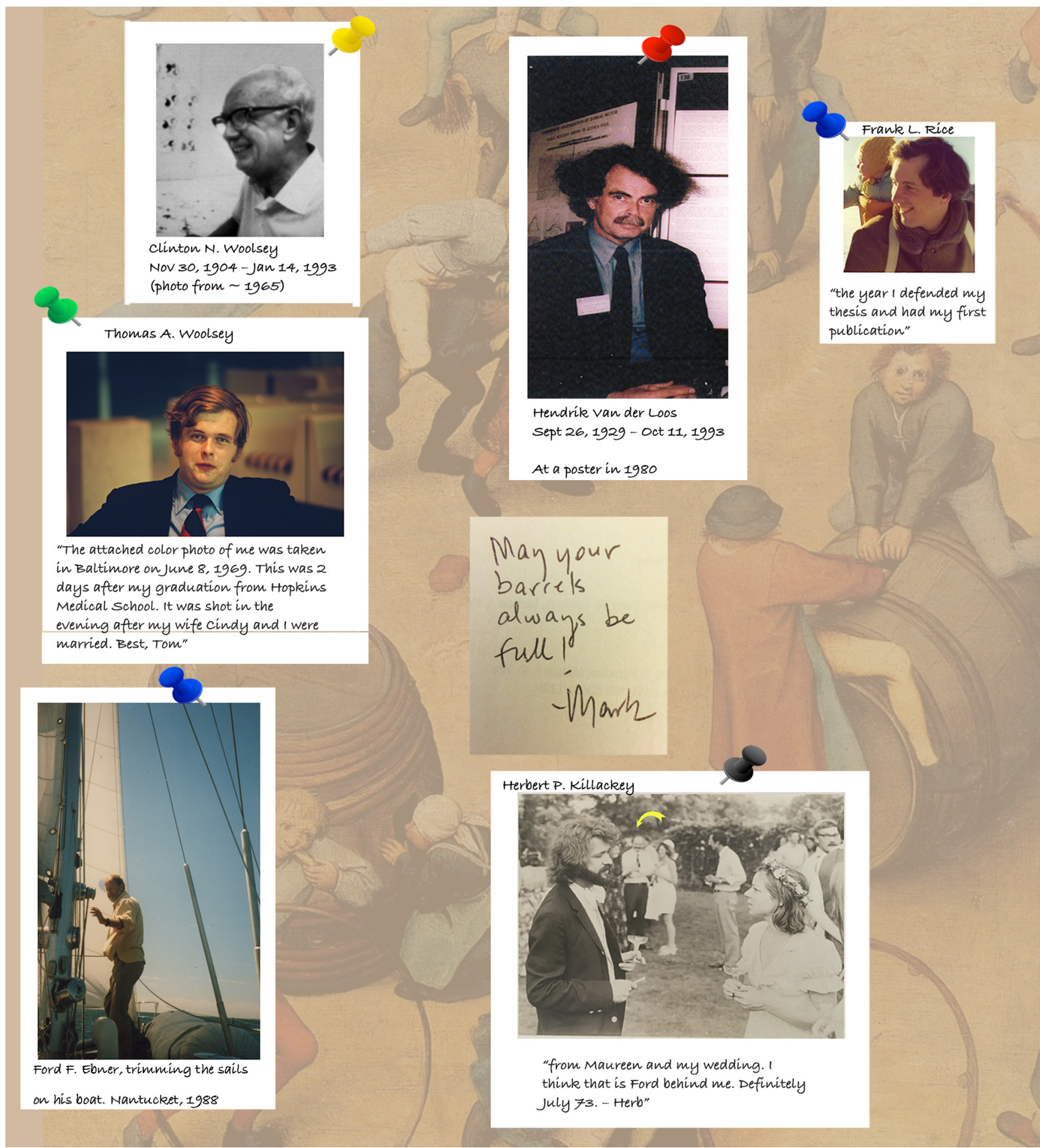

Figure 1. Barrel research pioneers. Photographs of Tom Woolsey's father Clinton Woolsey taken around 1965 and Tom Woolsey, right after the first barrels paper was submitted, but before its acceptance, from a happy time, the evening of his wedding. Hendrik Van der Loos, at a poster in 1980. Frank Rice in Switzerland, the year he defended his PhD thesis. Herb Killackey, at his wedding in Providence, Rl, in 1973, with Ford Ebner in the background. Bottom left, Ford Ebner in 1988, preparing to sail to "the ocean of barrel cortex plasticity" in the years to come (photograph by R.S.E.). Autograph in the middle of the figure is that of Mark Bear (a former student of F. Ebner) from 1995, when he was visiting R.S.E. at Louisiana State University Health Sciences Center in New Orleans. We are grateful to Tom Woolsey, Frank Rice, and Herb Killackey for providing the original photographs of the discoverers and pioneers, just when all was happening and they were enjoying happy times in their lives.

suggested that the same histochemical staining could be used for visualization of the barrel patterns in normal and neonatally vibrissa-removed mice (Wong-Riley and Welt, 1980). Succinic dehydrogenase, another mitochondrial marker, was found by Gary Belford (then a graduate student of Herb Killackey) to be another useful marker of the barrel cortex. The prevailing thought then was that cortical "activity levels of SDH or CO closely corresponded to the patterns of thalamocortical afferent terminals" (Killackey and Belford, 1979), but, although enriched in axon terminals, mitochondrial enzymes label both the presynaptic and 


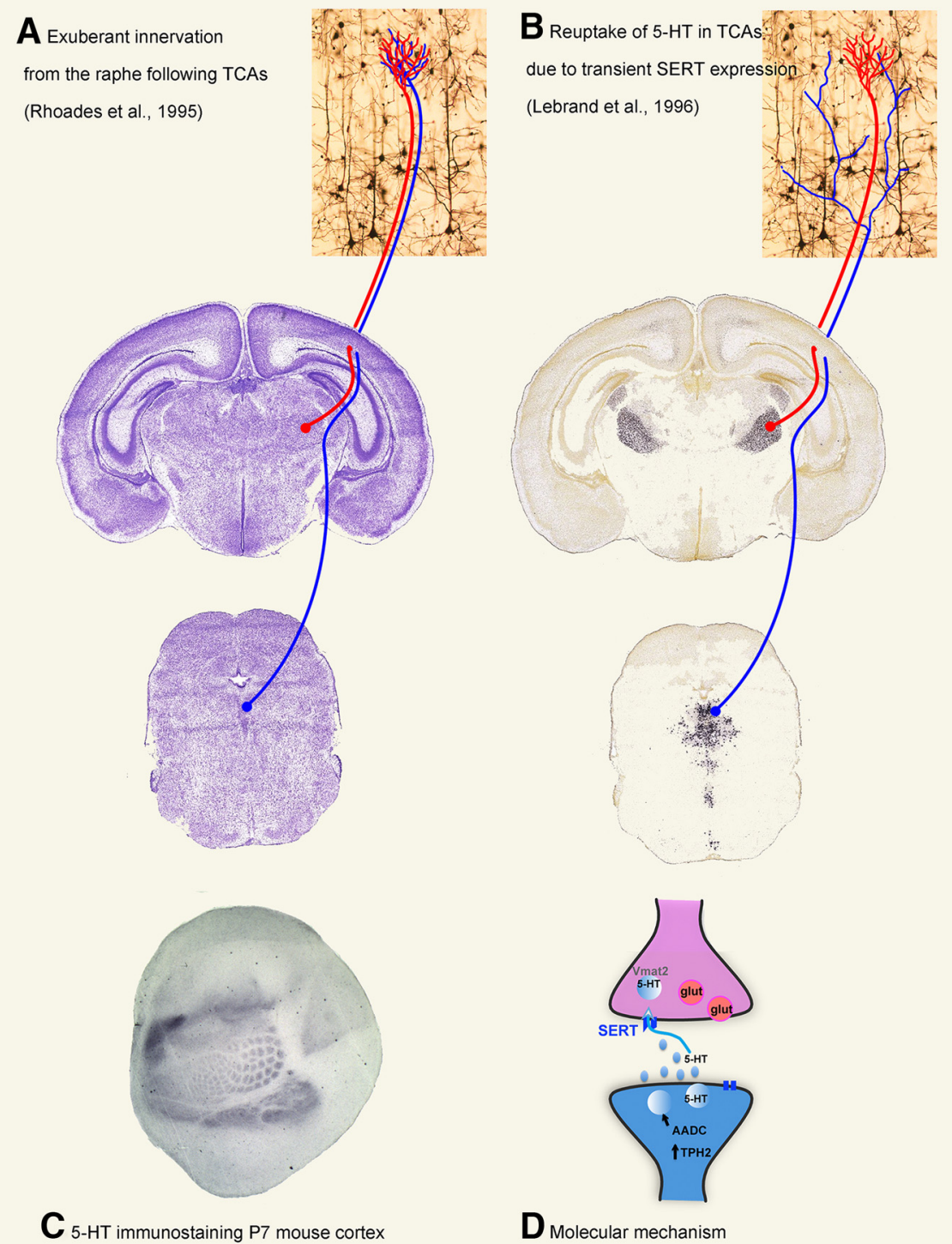

Figure 2. In a landmark paper published in 1987, D'Amato et al. (1987) reported the presence of a transient, dense, serotonergic innervation in all primary sensory areas of cortex, including the barrel cortex $(\boldsymbol{A})$. This is visible on tangential sections of cortex at P7 $(\boldsymbol{C})$ and was interpreted as an exuberant serotonergic innervation from the raphe, which followed sensory TC axons and was subsequently pruned $(\boldsymbol{A})$. Later observations (Lebrand et al., 1996) demonstrated that serotonin (5-HT) is indeed captured by the developing sensory TC axons because of the expression of the serotonin transporter (SERT/SIC6a3) and the vesicular monoamine transporter (VMAT2/SIC18a4) in the sensory thalamic neurons. The expression of these 2 genes starts in embryonic life (EXIV) and ends during the second postnatal week (P10) in mice. B. Thus, raphe neurons are not exuberant, but 5 -HT staining reflects transient neurotransmitter properties of glutamatergic thalamic sensory neurons. As schematized in $\mathbf{D}$, raphe brainstem neurons (blue) synthesize 5-HT via 2 enzymes, tryptophan hydroxylase (TPH2) and amino acid decarboxylase (AADC). Axon terminals of raphe neurons release 5-HT in the developing brain/ cortex, which is captured from the extracellular space by glutamatergic (glut) neurons (pink) that express the high-affinity membrane transporter, SERT. In the cytoplasm, 5 -HT is then concentrated into synaptic vesicles by VMAT2, where it is protected from monoamine-degrading enzymes, in particular monoamine oxidase (MAOS). Nissl and SERT ISH images are from the Allen Brain Atlas: Mouse Brain (Slc4-79591679).

postsynaptic elements (Kageyama and Wong-Riley, 1982). Because of the simplicity of $\mathrm{CO}$ staining and the clear delimitation of barrel topology it provided in cortical flat mounts, $\mathrm{CO}$ histochemistry took over and has been used ever since to visualize barrels.

Serotonin immunocytochemistry (Fig. 2A), AChE histochemistry (Kristt, 1979; Schlaggar and O'Leary, 1994), and labeling of extracellular matrix molecules started to be investigated at that time because of their precocious appearance and the observation that they clearly labeled the barrels at early stages (Cooper and Steindler, 1986; D'Amato et al., 1987; Steindler et al., 1989; Rhoades et al., 1990). Serotonin labeling in the barrel cortex was initially interpreted as a transient overgrowth of raphe axons into the somatosensory cortex (D'Amato et al., 1987; Rhoades et al., 1990) (Fig. 2A). However, later studies showed that there is no exuberant innervation from the raphe but that serotonin is indeed taken up in TC terminals (from E15 to P10) through transient expression of the serotonin transporter (5-HTT, SERT, Slc6a4) and the vesicular monoamine transporters (VMAT2, Slc18a2) in the developing thalamus (Lebrand et al., 1996, 1998) (Fig. 2B,D). Serotonin or SERT immunocytochemistry has since then been used as markers of the developing TC axons. More recently, SERT expression in the developing TC axons has been used to create genetically modified mice in which the SERT promoter drives GFP expression (Moreno-Juan et al., 2017; Mizuno et al., 2018).

Other useful markers of barrels have emerged since. In particular, vesicular glutamate transporter 2 (VGluT2), one of the two isoforms of the vesicular glutamate transporter, was found to be expressed selectively in the TC afferents (Nahmani and Erisir, 2005), and VGluT2 immunocytochemistry rapidly became a standard for analyzing barrel cortex (Fig. 3) (Liguz-Lecznar and Skangiel-Kramska, 2007; Nakamura et al., 2007).

\section{TC axons as major players of barrel development}

In the discussions centered around what initiated the barrel patterns in the cortex, a main issue in the early days was the difficulty of tracing axons in developing brains. An important turning point was brought about in 1987 , by the introduction of the lipophilic carbocyanine dyes that could be used as neuronal tracers in fixed tissues (Godement et al., 1987). Carbocyanine dye labeling and single-axon reconstruction along the barrel system revealed that TC axons begin invading the cortical plate at the time of birth in both mice and rats (Erzurumlu and Jhaveri, 1990; Senft and Woolsey, 1991). This allowed Erzurumlu and Jhaveri $(1990,1992)$ to document the time course of TC axon development in the parietal cortex. Simultaneous labeling of TC axons and raphe cortical projections with different colored carbocyanine dyes in the same brain (Erzurumlu and Jhaveri, 1992), 


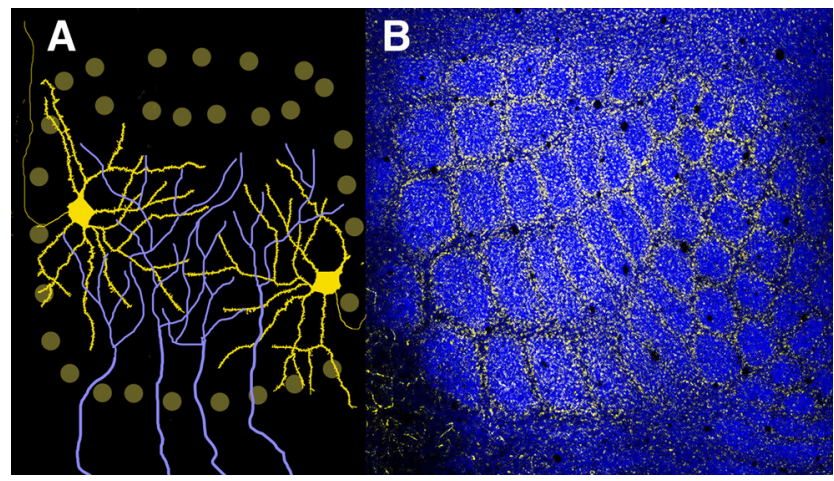

Figure 3. A, What is in a barrel? Glutamatergic spiny stellate and star pyramidal cells (yellow) of layer 4 aggregate along the walls of a barrel in the mouse $\mathrm{SI}$ cortex. Their dendrites orient toward the barrel hollows that are filled with the terminal arbors (blue) of TC axons from the whisker representation (barreloid) zone of the VPM. Axons of barrel cells project mostly to the supragranular (2/3) layers. $\boldsymbol{B}$, Photomicrograph of a PND7 mouse barrel cortex immunostained for VGluT2 (blue), a marker for TC axons, and NeuN (yellow) to mark the nuclear architecture of layer 4.

or comparisons of carbocyanine dye labeling of thalamic afferents and serotonin immunocytochemistry in opposite hemispheres of the same brain (Blue et al., 1991), proved that TC axons are the first pattern forming elements, while clustering of neurons in layer 4 occur 1 d later.

\section{How mouse genetics opened a window to the mechanisms underlying barrel formation}

The use of mouse genetics to study barrel cortex development was started in the1980s by Hendrik Van der Loos and Egbert Welker in Lausanne. This involved labor-intensive screening of mice with spontaneous mutations that led to abnormal number and patterns of vibrissae and/or barrel fields. By the 1980s, it was well established that the sensory periphery plays an instructive role in barrel patterning; damage to whisker follicles or the presence of supernumerary vibrissae on the snout (Van der Loos et al., 1986; Welker and Van der Loos, 1986) had predictable consequences in brain regions representing the vibrissae.

A surprising observation was that of a spontaneous mutation in which no barrels formed in the cortex despite a normal whisker pad and normal barrel patterning in the brainstem and thalamus (Welker et al., 1996). In these mice, TC axons form broader terminations, barrels do not develop, and whisker receptive fields of cortical cells are broader (Welker et al., 1996; Gheorghita et al., 2006). This mutation was identified, a few years later (Abdel-Majid et al., 1998), as a spontaneous disruption of the adenylate cyclase 1 gene $(A c 1)$.

At exactly the same time as discovery of the "barrelless" mutation, another mouse mutant with a similar phenotype was discovered by one of us (P.G.) while conducting research on the developmental role of serotonin (5-HT). Mouse mutants with excess 5-HT, resulting from disruption of the monoamine oxidase A (Maoa) gene, had no barrels, but normal patterning in the thalamus and the brainstem. These effects were reversed (barrels formed) by reducing 5-HT levels and were replicated by pharmacological blockade of MAOA during the critical period. Previously, it was reported that $5-\mathrm{HT}_{1 \mathrm{~B}}$ receptors are also transiently expressed in the developing thalamus (Bennett-Clarke et al., 1993), and 5-HT has a role in inhibiting glutamate release (Rhoades et al., 1994). The Gaspar group took this a couple steps further; with genetic tools, they showed that lack of 5- $\mathrm{HT}_{1 \mathrm{~B}}$ rescued the phenotype of Maoa KO mice (Salichon et al., 2001).
Whole-cell patch-clamp recordings of layer 4 neurons showed a strong presynaptic inhibitory effect of $5-\mathrm{HT}_{1 \mathrm{~B}}$ signaling on $\mathrm{TC}$ axons (Laurent et al., 2002). Collectively, these findings demonstrated that TC axons autoregulate their glutamate release via extracellular 5 - $\mathrm{HT}$ binding to their $5-\mathrm{HT}_{1 \mathrm{~B}}$ receptors. Although the phenotypes of Maoa and Ac1 KO are very similar, it remains unclear whether they share similar mechanisms.

Other genetically modified mouse models are discussed in the following sections.

\section{Development of TC axons: first encounters guide topography}

Along the trigeminal pathway, axon navigation and pattern formation do not follow a sequential order from the periphery to the cortex. Rather, they happen concurrently (Iwasato and Erzurumlu, 2018). In mice, TC axons from the ventroposteromedial nucleus (VPM) are already at the diencephalon-telencephalon border by embryonic day (E) 12.5 (López-Bendito et al., 2006; Antón-Bolaños et al., 2018), well before the trigeminothalamic afferents reach the VPM around E15.5 (Kivrak and Erzurumlu, 2013).

TC axons are preordered and maintain near-neighbor relationships as they navigate through the subpallium (Molnár et al., 2012). Perturbation of subpallial development by conditional inactivation of the transcription factor Ebfl leads to misrouting of the TC axons and disruption of their topography and patterning in the barrel cortex (Lokmane et al., 2013). The role of axon fasciculation in establishing topographic organization in the barrel map is nicely illustrated in mouse mutants in which the trigeminothalamic axons project bilaterally (Renier et al., 2017) and form distinct ipsilateral and contralateral domains in the VPM. In these mice, TC axons segregate into two independent barrel cortices that lie side by side, suggesting that axons traveling together prefer remaining together rather than following topographic rules (Renier et al., 2017; Gaspar and Renier, 2018).

TC axons arrive below the cortical plate by E13.5, before the differentiation of the prospective barrel site in layer 4 (Erzurumlu and Jhaveri, 1990; Senft and Woolsey, 1991; Catalano et al., 1996). They transiently interact with subplate cells, forming functional synapses (for review, see Kanold and Luhmann, 2010). Early ablation of subplate neurons during embryonic life prevents thalamic axons from penetrating into the cortex (for review, see Hoerder-Suabedissen and Molnár, 2015). Processes of the subplate cells continue to interact with TC axons well into the early postnatal period during whisker-related patterning of TC axons (Piñon et al., 2009), and immunotoxic lesions of the subplate disrupt barrel formation (Tolner et al., 2012).

\section{Shaping TC axons into barrel clusters}

Whether TC axons are already topographically organized in barrel domains when they reach the cortex or whether peripheryrelated organization emerges later has been debated. In the mouse brain, Senft and Woolsey (1991) described TC axon terminals as "whisker-related Gaussians" that initially overlap but later (after postnatal day [PND] 4) segregate into whisker-related patches as appropriate collateral branches are elaborated and inappropriate ones pruned. In the rat, Catalano et al. (1996) described a simpler development, in which single axonal arbors had fewer branches initially and became elaborated without exceeding barrel boundaries. A later carbocyanine-dye-labeling and single-axon-reconstruction study in the mouse (Agmon et 
al., 1993) documented that TC axons course through layers 6 and 5 with little or no branching on PND0, develop lower-tier branches at the border of layers 5 and 6 by PND2, and begin elaborating patchy dense clusters in layer 4 by PND4. The authors concluded that TC terminals in layer 4 projected from the deep tier and "do not develop from an initially profuse arborization pattern through pruning of inappropriate branches." The P.G. and R.S.E. laboratories conducted single-TC axon reconstruction studies in $(\mathrm{C} 3 \mathrm{H}$ and $\mathrm{C} 57 \mathrm{Bl} / 6)$ mice and compared them with those from Maoa and NR1 (Grin1) KO mice, respectively (Rebsam et al., 2002; Lee et al., 2005) and showed a somewhat different picture, with earlier branching in layer 4 and lack of prepatterning in deep layers. These results paved the way for future studies with KO models to sort out the role of presynaptic versus postsynaptic elements in pattern formation.

\section{Presynaptic and postsynaptic communication in barrel formation}

Mouse models with region-specific gene $\mathrm{KO}$ have been powerful instruments in dissecting the roles of presynaptic and postsynaptic elements of TC circuits in pattern formation. This approach became feasible with the introduction of site-specific recombination in mice using the Cre-lox recombination (Sauer and Henderson, 1988; Tsien et al., 1996). The first of these mouse lines involved KO of Grin1 (NMDA receptor subunit 1) in excitatory cortical neurons (Iwasato et al., 2000). In these mice, layer 4 neurons failed to orient their dendritic trees and TC terminals developed extensive arbors that did not focalize in layer 4 (Iwasato et al., 2000; Datwani et al., 2002b; Lee et al., 2005). A similar glutamatergic transmission defect was reported for cortex-specific metabotropic glutamate receptor $m G l u R 5 \mathrm{KO}$ mice (Ballester-Rosado et al., 2010).

Obviously, the main questions in site-specific gene deletions were whether TC patterning and dendritic orientation of barrel cells depended on each other. These questions were addressed in mosaic cortical-gene-deletion models, in which only a subset of layer 4 neurons lost Grin1, Grin2, or mGluR5. These studies revealed that lack of one of these glutamate receptors alters dendrite organization of layer 4 neurons (Espinosa et al., 2009; Ballester-Rosado et al., 2010; Mizuno et al., 2014).

Genetic ablation of thalamic Grin1 or Ac1, an enzyme that increases cyclic AMP in response to calcium influx, led to absence of barreloids in the thalamus and subsequently barrels in the cortex (Iwasato et al., 2008; Arakawa et al., 2014b; Suzuki et al., 2015). Despite the absence of neuronal aggregate patterns, in both instances, some whisker-related patterning of TC could be seen. Along similar lines, thalamus-specific deletion of RIM1 and RIM2 proteins, which control synaptic vesicle fusion and neurotransmitter release, yielded a phenotype with absence of barrels as cellular aggregates but presence of distinct TC terminal patterns in the whisker representation area (Narboux-Nême et al., 2012). Thus, it appears that, when thalamic cells lose NMDAR or AC1 function or have significantly reduced presynaptic glutamate release from their terminals (thalamic Rim1/Rim2 double $\mathrm{KO}$ ), the TC axons can still manage to form faint or partial whisker-related patterns in the barrel cortex. Nonetheless, with complete deletion of glutamatergic transmission in the VPM, in VGluT1-VGluT2 double KO, TC axons do not form patterns in the cortex (Li et al., 2013).

Recently, evaluation of barrel phenotype in staggerer mice (with a mutation of the gene encoding the retinoic acid-related orphan receptor $\alpha[\operatorname{ROR} \alpha]$ ) revealed disruption of patterns both in the thalamus and cortex. Conditional Ror $\alpha$ deletion in the thalamus or cortex showed that $\operatorname{ROR} \alpha$ is cell-autonomously required in the thalamus for clustering of TC axons and dendritic maturation of layer 4 neurons in the barrel cortex (Vitalis et al., 2018). In an earlier study, Matsui et al. (2013) found that dendritic orientation of barrel cells is controlled by the $\mathrm{BTB} / \mathrm{POZ}$ domain-containing 3 (BTBD3) transcription factor, and when ectopically expressed in the ferret visual cortex, BTBD3 directs dendrites of cortical cells toward active axon terminals. Interestingly, BTBD3 appears to be controlled by the transcription factor Lhx2 discussed above (Wang et al., 2017).

Despite all these elaborate genetic studies, almost half a century after the first description of patterning of whisker-related TC terminals in the rodent barrel cortex (Killackey, 1973; Killackey and Leshin, 1975), we still do not know the exact mechanisms by which the TC axon terminals form clusters, replicating the distribution of whisker follicles, three synapses away from the periphery. Nonetheless, the emerging picture is that whiskerrelated TC axons begin focalizing their terminals in an activitydependent manner. During this process, they regulate their own glutamate secretion through $5 \mathrm{HT}-1 \mathrm{~B}$ receptors binding extracellular serotonin delivered to the cortex via raphe terminals (Bennett-Clarke et al., 1993, 1996, 1997; Lieske et al., 1999; Young-Davies et al., 2000; Salichon et al., 2001). Focalized activity of TC axon terminal patches is detected by the postsynaptic spiny stellate and star pyramid cells (barrel cells) in an NMDA receptor-dependent manner, and $\mathrm{BTBD} 3$ directs orientation of barrel cell dendrites toward the TC terminal patches, subsequently forming the barrel rings. In vivo time-lapse imaging of labeled TC axons and individual barrel cell dendrites revealed dynamic orientation of the dendrites toward focalized TC patches; and in NMDAR-deficient barrel cells, the motility increased and orientation bias failed to develop (Mizuno et al., 2014; Nakazawa et al., 2018).

Curiously, the barrels in the rat cortex resemble those of the mouse cortex with cell-sparse centers until PND20, and then barrel centers become uniformly cell-dense (Rice, 1985a), despite the patterning of TC axons.

\section{Specification of sensory cortices: intrinsic versus extrinsic determinants}

The development of TC axons and their major impact on the formation of barrels became a central model in the broader debate on the mechanisms underlying specification of cerebral cortical areas (Rakic, 1988; O'Leary, 1989). Two main hypotheses were discussed at the time. One hypothesis was that the neocortex is a "tabula rasa" on which TC axons impress their characteristics. Strong support for this hypothesis was provided by the whisker lesion studies showing that sensory input was crucial to imprint barrel patterns and by grafting experiments showing that pieces of visual cortex transplanted into the somatosensory cortex could develop TC axon patches (Schlaggar and O'Leary, 1991). Furthermore, when visual or auditory inputs were rerouted to the somatosensory thalamus, the somatosensory cortex would become responsive to visual or auditory cues (Gao and Pallas, 1999; Frost et al., 2000; Sharma et al., 2000).

An alternative hypothesis held that there are intrinsic cortical cues (proto map) that direct TC axon connectivity. In support of this hypothesis, Rakic et al. (1991) provided evidence that reducing the population of selected thalamic fibers projecting into the primary visual cortex of monkeys during midgestation induced the formation of a novel cytoarchitectonic area, which they called 
area X. Topographic projections from the visual thalamus to the primary visual cortex of congenitally anophthalmic mice (Kaiserman-Abramof et al., 1980) strengthened this hypothesis. Several years later, more evidence came from the barrel cortex. This was based on the finding of a transgene $(H-2 Z 1)$, of unknown function, but whose expression was found to be intrinsic to layer 4 of the somatosensory cortex. Expression of $H-2 Z 1$ was found to be independent from sensory inputs, and to persist in heterotopic grafts and in cultured explants (Cohen-Tannoudji et al., 1994; Gitton et al., 1999). The balance of evidence shifted further toward the "proto map" hypothesis with the seminal paper by Fukuchi-Shimogori and Grove (2001), showing that cortically secreted signaling molecule FGF8 determines the sites of different sensory areas.

We now know that the neocortex is not a "tabula rasa"; instead, spatiotemporal regulation of morphogens, some of which are induced by sensory afferents, regulates the areal parcellation (Frangeul et al., 2016). Indeed, a variety of intrinsic cortical signaling molecules involved in positioning and patterning barrel maps have been discovered (Zembrzycki et al., 2013, 2015; Stocker and O'Leary, 2016; for review, see Simi and Studer, 2018), and developmental studies using the barrel cortex as a model have revealed many important mechanisms underlying specification and arealization of the mammalian cerebral cortex.

\section{Molecular signals involved in cortical specification}

Cortical cues that are produced very early in development shape the regional identity and define the position and dimensions of the prospective somatosensory cortex (and other primary sensory cortices). These signals will, in turn, attract specifically VPM TC axons. Along the rostrocaudal and mediolateral dimensions of the telencephalic vesicles that give rise to the neocortex, diffusible morphogens and signaling molecules, such as Fgf8, Pax6, Emx2, Sp8, and Couptf1, establish a fate map area in the ventricular zone. This fate map is later transferred to the cortical plate and defines the location and boundaries of the primary sensory, motor, and association areas (Greig et al., 2013). The development of in utero electroporation techniques permitted ectopic manipulation of morphogen expression in the embryonic cortex, and the resulting phenotypes were quite amazing, leading to altered positioning of the barrel cortex along the rostrocaudal dimension of the brain hemisphere. Most remarkably, creating two sources of fibroblast growth factor (fgf8) on either pole of the telencephalic vesicle led to duplicate barrel fields (FukuchiShimogori and Grove, 2001) and expression in multiple points led to multiple fractured barrel maps (Assimacopoulos et al., 2012). Similarly, manipulation of Pax6, Emx1, or Lhx2 in early embryos led to differential expansion or contraction of primary sensory cortical areas (Zembrzycki et al., 2013, 2015; Stocker and O'Leary, 2016). Interestingly, the early sensory TC inputs to the cortex contribute to the expression of region-specific transcriptomes, as removal of these inputs leads to a respecification of the primary somatosensory area into associative or secondary sensory area (Vue et al., 2013; Pouchelon et al., 2014; Frangeul et al., 2016).

At somewhat later stages in development, when corticogenesis is underway, other molecular cues are important to guide TC axons to their proper cellular targets (López-Bendito et al., 2006). Cortical principal (glutamatergic) neurons are highly diverse in terms of connectivity and physiology. Although cortical identity was initially defined by laminar position, it is increasingly becoming clear that identity is defined by birth order and by molecular profile, which in turn determines a preferred connectivity (Greig et al., 2013; Govidan and Jabaudon, 2017). TC axons from the VPM preferentially target layer 4 spiny stellate neurons (Simi and Studer, 2018). Changes in the laminar position of layer 4 neurons as a result of migration defects does not alter this preferential targeting. For example, in the reeler mouse, different types of cortical neurons are intermingled in a chaotic fashion because the normal inside out migration of cortical neurons is disturbed. Despite the shuffling of cortical neurons, TC axons recognize stellate neurons, target them, and form rudimentary barrel-like patterns. More importantly, whisker stimulation evokes activity in somatotopically organized barrel columns (for review, see Guy and Staiger, 2017). Conversely, mutations of transcription factors that alter the identity of cortical neurons, and of layer 4 neurons in particular, cause alterations in TC axon branching and formation of barrel patterns. The first example of such alterations was in cortex-specific deletion of the transcription factor Lhx2. TC axons were directed to the appropriate cortical region but did not form barrels (Shetty et al., 2013; Wang et al., 2017). A somewhat similar phenotype was recently observed in a cortex-specific deletion of the transcription factor Ror $\alpha$, which is selectively expressed in layer 4 (Vitalis et al., 2018). Lhx2 and $\operatorname{ROR} \alpha$ control the expression of several guidance molecules, such as semaphorin7a and EphrinA5, that are expressed in layer 4 neurons and are important in the control of terminal branching of TC axons (Uziel et al., 2008; Carcea et al., 2014). Finally, a more severe disorganization of TC axons and complete disruption of the sensory map were noted in mutants of other transcription factors, such as Ctip1-KO mice (Greig et al., 2016). Ctip1- KO neurons were nonpermissive to TCA ingrowth but permissive to cortical callosal projections. Overall, these results indicate that molecular recognition and attraction cues are guided by timely and coordinated expression of transcription factors in thalamic and layer 4 neurons (Fig. 4).

\section{Spontaneous activity in developing neural circuits of the whisker-barrel system}

Mice and rats do not start whisking until the second postnatal week; but as the pups huddle, suckle, and move about, their snouts are stimulated. Trimming of whiskers, even at such early stages, causes behavioral alterations (Arakawa and Erzurumlu, 2015). Thus, even without whisking, passive tactile stimulation of whiskers is meaningful to the developing mouse brain. Indeed, more and more studies are finding that whisker deflections during early development evoke cortical activity, and these can be synchronized with spontaneous activity in thalamic neurons (Minlebaev et al., 2011; Akhmetshina et al., 2016). Moreover, spontaneous whisker movements in neonates, even while sleeping, can drive cortical activity (Khazipov et al., 2004; Tiriac et al., 2012). Extracellular and whole-cell recordings from the barrel cortex of neonatal rat pups revealed that there is a low level of tuning of presumptive barrel neurons to the principal whisker as early as PND0-PND1, before the barrels as neuronal clusters form (Mitrukhina et al., 2015). The same study further showed that a functional segregated whisker map emerges from PND2-PND3, in which individual neurons show preferential single whisker tuning.

Recently, Mizuno et al. (2018) adopted an elaborate strategy to image activity of layer 4 neurons in vivo in neonatal mice. They generated transgenic mice in which TC axons express RFP under control of the serotonin transporter promoter, which 


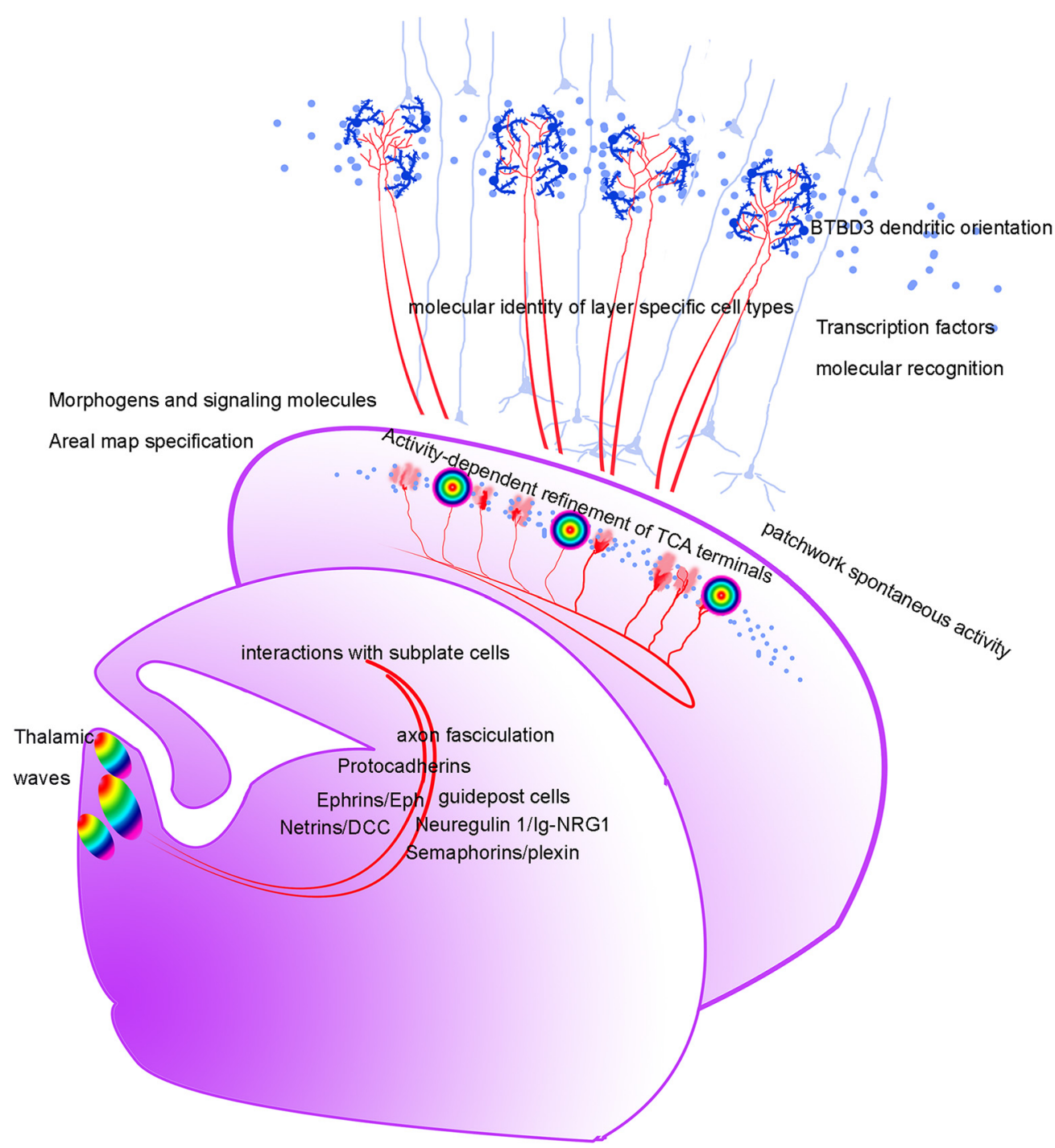

Figure 4. Diagram of the TC pathway and barrel formation in mice. Waves of calcium signals in the embryonic thalamus, schematically illustrated by graded colors, are suggested to correspond to a somatotopic connectivity between the thalamus and barrel cortex, before sensory input is present. Without these waves, barrel cortex becomes hyperexcitable and does not develop columnar and barrel organization (Antón-Bolaños et al., 2019). Developing TC axons are guided to cortex through multiple molecular guidance cues, some attractive and some repulsive (Antón-Bolaños et al., 2018). Morphogens and signaling molecules set up areal specification of the neocortex into primary sensory, motor, and association cortex areas (FukuchiShimogori and Grove, 2001; Assimacopoulos et al., 2012; Zembrzycki et al., 2013, 2015; Stocker and O'Leary, 2016). In the developing barrel cortex, a patchwork of spontaneous activity corresponds to barrels at the time of their formation (Mizuno et al., 2018). Layer- and projection-type-specific identity of neocortical neurons is determined by their time of differentiation and specific transcription factors (Greig et al., 2013; Govidan and Jabaudon, 2017). Transcription factor ROR $\alpha$ is cell-autonomously required in the thalamus for clustering of TC axons and dendritic maturation of layer 4 neurons in the barrel cortex (Vitalis et al., 2018). Dendritic orientation of barrel cells is controlled by the BTBD3 transcription factor (Matsui et al., 2013), and BTBD3 appears to be controlled by the transcription factor Lhx2 (Wang et al., 2017). So, transcription factors play multiple roles from cell specification to dendritic orientation in the barrel cortex.

labels these axons as described above to visualize barrel patterns, and they used in utero electroporation to express GCaMp6s in layer 4 neurons. They then analyzed spontaneous activity in relation to the barrels. They found that layer 4 neurons in the same barrel fire synchronously without peripheral stimulation, which the authors called "patchwork-type" spontaneous activity (Mizuno et al., 2018). Thus, even in the absence of peripheral sensory inputs, developing barrel neurons exhibit spontaneous correlated activity in a patterned ensemble.

\section{Critical-period plasticity}

Original studies on the barrel cortex (discussed earlier in this review) revealed that neonatal cautery of middle-row whisker follicles (row C) leads to shrinkage of the row $\mathrm{C}$ barrels into a thin, cigar-shaped band, and enlargement of barrels in neighboring rows B and D (Van der Loos and Woolsey, 1973; Woolsey and Wann, 1976; Belford and Killackey, 1979; Killackey and Belford, 1979; Woolsey et al., 1979). This effect occurs only if the follicle damage is done during the first few days after birth. Woolsey referred to this period as the "critical period" (Woolsey et al., 1979), whereas Belford and Killackey (1980) chose the term "sensitive period." In a review of critical, sensitive, vulnerable, and optimal periods in development, Erzurumlu and Killackey (1982b) pointed out: "The conceptual difference between the terms critical period and sensitive period is a very important one. The first denotes a period during which the presence of certain critical conditions is necessary for the nervous 
system to develop normally and the other to a time during which damage to the nervous system can lead to alterations or reorganization of the system" (p. 208). The term "critical period" migrated to the whisker-barrel system from early monocular deprivation studies in the visual system (Wiesel and Hubel, 1963). In visual system critical-period plasticity, visual cortex is selectively deprived from inputs coming from one eye, without any retinal damage. In contrast, early injury to the whisker follicles or the infraorbital nerve, which innervates all the whisker follicles, interferes with the normal wiring of the central circuits. Despite emphasis on these fundamental differences between the two paradigms, the term "critical period" became more widely used in the field.

In pioneering experiments, Belford and Killackey (1980) concluded that the system was "sensitive" to follicle damage up to PND3 at all three stations: the brainstem, thalamus, and cortex in rats. This diverged from the conclusions of the Woolsey group of different "critical periods" for each station: the cortical one closing at PND6 and the thalamic one at PND4 in mice (Woolsey and Wann, 1976; Durham and Woolsey, 1984; Woolsey et al., 1979). Later studies (as discussed below) confirmed that, in both the rat and the mouse, the sensitive or critical period for anatomic plasticity closes by PND4.

To date, there is no clear understanding of what closes the critical period of morphologic plasticity induced in the rodent brain by whisker follicle damage. Several studies suggested that the barrel cortex critical period is tied to a developmental switch of cortical and thalamic expression of NMDA receptor subunits (Crair and Malenka, 1995; Celikel et al., 2004; Liu et al., 2004; Daw et al., 2006; Itami and Kimura, 2012; Itami et al., 2016). Curiously, however, a developmental switch in NMDA receptor NR2A/NR2B subunits does not occur in the developing trigeminal principal sensory nucleus in the brainstem, where plasticity resulting from follicle damage should first take place (Lo and Zhao, 2011). Furthermore, in NR2A KO mice, NMDA subunit composition and kinetics remain immature past the end of the critical period, but there is no extension in the closure of the critical period (Lu et al., 2001).

An early pharmacological blockade study led to the conclusion that NMDA receptors play an important role in determining the duration of the plasticity period in the rat barrel cortex (Schlaggar et al., 1993). However, a role for NMDA receptors in closing the plasticity period in barrel cortex was not confirmed in NMDA receptor KO mice (Datwani et al., 2002a). Thus, available data rule out an essential role for NMDA receptors in critical-period plasticity, at least during the developmental, morphologic critical period, which ends by PND4 in mice, even when mice are prematurely born (Toda et al., 2013). Despite the negative findings from $\mathrm{KO}$ mice with nonfunctional NMDA receptors, studies of the critical period in the barrel cortex expanded to explore processes that typically depend on NMDA receptors, including LTP, LTD, spike-timing-dependent plasticity, and expression of silent synapses.
Maoa KO mice allowed a different approach to test whether barrel cortex critical-period plasticity could be extended by delaying TC terminal patterning and barrel formation (Rebsam et al., 2005). In Maoa KO mice, excess 5-HT blocks patterning of TC axon terminals into whisker-specific patterns (Cases et al., 1996). Pharmacological treatment to reduce 5-HT levels permits formation of TC axon terminal patches. Rebsam et al. (2005) took this approach and delayed TC axon terminal patch formation by $3 \mathrm{~d}$, and tested whisker lesion-induced plasticity. They found that, even when barrel formation is delayed by $3 \mathrm{~d}$, the closure of whisker follicle injury-induced plasticity was unchanged (Fig. 5). These findings were interpreted as evidence favoring closure of the critical period in subcortical structures.

Overall, the factors governing the duration and expandability of the critical window during which the system is sensitive to peripheral damage are still unknown.

Other studies searched for critical periods in the true sense of sensory input deprivation, akin to visual system monocular deprivation, experimentally induced strabismus, or amblyopia. Most of these were done in rats by trimming all of the whiskers close to the fur, sparing a single whisker, leaving a pair of whiskers, or a mosaic of whiskers. They found expansion of the receptive fields of the barrel cells corresponding to the spared whiskers (Land and Simons, 1985; Fox, 1992, 2002; Diamond et al., 1994; Wallace and Fox, 1999; Trachtenberg et al., 2002; Allen et al., 2003). Experience-dependent cortical plasticity studies revealed multiple critical periods. More recent studies are expanding the concept of critical periods and barrel cortex plasticity to cellular and molecular levels involving neurons, glia, and endothelial cells (and adaptive changes at the molecular levels) (Kole et al., 2018).

Collectively, the above documented findings, and several others, are pointing to different forms of plasticity, sensitive periods, and critical periods during which damage to the sensory periphery or altered sensory experience along the whisker-barrel pathway can shape the morphology and function of cortical circuits throughout life. 


\section{Concluding remarks and future directions}

Half a century of research on the rodent barrel cortex brought us amazing insights into cellular and molecular mechanisms of neural development and plasticity. What started with simple Nissl stains and crude fiber tracings evolved into finer and finer analyses as new techniques got introduced. Many studies in the field of development have used the rodent whisker-barrel pathway as a model system to study axon-pathfinding with a strong focus on TC (Antón-Bolaños et al., 2019) and tactile sensory circuits (Iwasato and Erzurumlu, 2018). Other developmental studies made use of the exquisite patterning of neurons and TC axons in the cortex to disentangle the mechanisms underlying activity-dependent remodeling of axons and dendrites (Erzurumlu and Gaspar, 2012) and the rules of cortical area specification and patterning (Simi and Studer, 2018). Manipulation of the mouse genome played a major role in this respect. Mouse genetics that initially started with a crude and labor-intensive approach in Lausanne in the late 1970s flourished with generation of numerous transgenic mouse lines. Molecular genetics allowed deleting or introducing genes in the different relays of the whisker-to-barrel pathway and thus identified transcription factors, neurotransmitters, and guidance molecules that are required for barrel formation. In the field of sensory physiology, the rodent barrel cortex took over the studies investigating many forms of plasticity, which were traditionally done in the visual system. Advances in optogenetics and in vivo imaging of neural activity in awake and behaving mice have found fertile ground for application in the barrel cortex to explore the underpinnings of sensory processing and plasticity. As our technology toolbox gets richer, barrel cortex will undoubtedly serve as a model for many years to come.

Some outstanding questions in the field of development still remain unanswered. The nature of the signal(s) derived from the sensory receptors that instructs a "one-to-one" mapping of individual whiskers along the trigeminal pathway (including when the routing of the axons is derailed) remains unknown. Despite five decades of research, we still do not know why inputs derived from one whisker cosegregate all along the sensory pathway and what could be the functional role of this discontinuous topographical organization for perception. Indeed, sensing the environment with whiskers implies an integration of signals rather than single whisker processing. The morphologic differences in barrel organization as cellular aggregates with hollow centers (mice) and cell-dense centers (rats) do not seem to matter much for whisker-sensory behaviors, as long as whisker-specific segregation of TC axons couples with aggregates of postsynaptic layer 4 cells. On the other hand, when the barrel patterning is diminished or absent as in Ac1 KO, thalamus-specific Ac1 or Grin1 KOs, and in mice with a bifacial map with reduced barrel sizes for ipsilateral and contralateral whisker representations, whiskerdependent sensory discrimination and performance become impaired (Arakawa et al., 2014a,b; Tsytsarev et al., 2017).

A somewhat related question, which is now being actively explored, is how the segregated sensory inputs arriving to one barrel become distributed to other neurons of the sensory cortex (Egger et al., 2020) and other cortical and subcortical structures (Aronoff et al., 2010; Yamashita et al., 2018) to extract and synthesize/integrate useful information for sensorimotor processing (Petersen, 2019) and complex behavior (Yang et al., 2018).

Finally, the mouse barrel cortex is making advances in understanding cellular and molecular mechanisms underlying sensory and cognitive deficits associated with neurodevelopmental disorders, such as autism spectrum disorders, fragile $\mathrm{X}$ syndrome, and Rett syndrome, and diseases of aging, such as Alzheimer's disease and related dementias, as mouse models with associated genetic defects are made available (Crouzin et al., 2013; Beker et al., 2016; Lo et al., 2016a,b; Maatuf et al., 2016; Lee et al., 2017; Lo and Erzurumlu, 2018; Booker et al., 2019; Domanski et al., 2019). Tactile sensory abnormalities or altered sensitivities are common features of both neurodevelopmental disorders and dementias. Cortical circuits that connect the primary somatosensory areas with frontal cortical association areas are gaining increased interest in understanding how these circuits subserving sensory perception and cognition are altered at the molecular and circuit level in mouse models of these conditions. Clearly, new insights will come out of these studies in the near future.

\section{References}

Abdel-Majid RM, Leong WL, Schalkwyk LC, Smallman DS, Wong ST, Storm DR, Fine A, Dobson MJ, Guernsey DL, Neumann PE (1998) Loss of adenylyl cyclase I activity disrupts patterning of mouse somatosensory cortex. Nat Genet 19:289-291.

Agmon A, Yang LT, O’Dowd DK, Jones EG (1993) Organized growth of thalamocortical axons from the deep tier of terminations into layer IV of developing mouse barrel cortex. J Neurosci 13:5365-5382.

Akhmetshina D, Nasretdinov A, Zakharov A, Valeeva G, Khazipov R (2016) The nature of the sensory input to the neonatal rat barrel cortex. J Neurosci 36:9922-9932.

Allen CB, Celikel T, Feldman DE (2003) Long-term depression induced by sensory deprivation during cortical map plasticity in vivo. Nat Neurosci 6:291-299.

Antón-Bolaños N, Espinosa A, López-Bendito G (2018) Developmental interactions between thalamus and cortex: a true love reciprocal story. Curr Opin Neurobiol 52:33-41.

Antón-Bolaños N, Sempere-Ferràndez A, Guillamón-Vivancos T, Martini FJ, Pérez-Saiz L, Gezelius H, Filipchuk A, Valdeolmillos M, López-Bendito G (2019) Prenatal activity from thalamic neurons governs the emergence of functional cortical maps in mice. Science 364:987-990.

Arakawa H, Erzurumlu RS (2015) Role of whiskers in sensorimotor development of C57BL/6 mice. Behav Brain Res 287:146-155.

Arakawa H, Akkentli F, Erzurumlu RS (2014a) Region-Specific Disruption of Adenylate Cyclase Type 1 Gene Differentially Affects Somatosensorimotor Behaviors in Mice. eNeuro 1:ENEURO.0007-14.2014.

Arakawa H, Suzuki A, Zhao S, Tsytsarev V, Lo FS, Hayashi Y, Itohara S, Iwasato T, Erzurumlu RS (2014b) Thalamic NMDA receptor function is necessary for patterning of the thalamocortical somatosensory map and for sensorimotor behaviors. J Neurosci 34:12001-12014.

Aronoff R, Matyas F, Mateo C, Ciron C, Schneider B, Petersen CC (2010) Long-range connectivity of mouse primary somatosensory barrel cortex. Eur J Neurosci 31:2221-2233.

Assimacopoulos S, Kao T, Issa NP, Grove EA (2012) Fibroblast growth factor 8 organizes the neocortical area map and regulates sensory map topography. J Neurosci 32:7191-7201.

Ballester-Rosado CJ, Albright MJ, Wu CS, Liao CC, Zhu J, Xu J, Lee LJ, Lu HC (2010) mGluR5 in cortical excitatory neurons exerts both cell-autonomous and -nonautonomous influences on cortical somatosensory circuit formation. J Neurosci 30:16896-16909.

Beker S, Goldin M, Menkes-Caspi N, Kellner V, Chechik G, Stern EA (2016) Amyloid- $\beta$ disrupts ongoing spontaneous activity in sensory cortex. Brain Struct Funct 221:1173-1188.

Belford GR, Killackey HP (1979) The development of vibrissae representation in subcortical trigeminal centers of the neonatal rat. J Comp Neurol 188:63-74.

Belford GR, Killackey HP (1980) The sensitive period in the development of the trigeminal system of the neonatal rat. J Comp Neurol 193:335-350.

Bennett-Clarke CA, Leslie MJ, Chiaia NL, Rhoades RW (1993) Serotonin 1B receptors in the developing somatosensory and visual cortices are located on thalamocortical axons. Proc Natl Acad Sci USA 90:153-157. 
Bennett-Clarke CA, Chiaia NL, Rhoades RW (1996) Thalamocortical afferents in rat transiently express high-affinity serotonin uptake sites. Brain Res 733:301-306.

Bennett-Clarke CA, Chiaia NL, Rhoades RW (1997) Contributions of raphecortical and thalamocortical axons to the transient somatotopic pattern of serotonin immunoreactivity in rat cortex. Somatosens Mot Res 14:2733.

Blue ME, Erzurumlu RS, Jhaveri S (1991) A comparison of pattern formation by thalamocortical and serotonergic afferents in the rat barrel field cortex. Cereb Cortex 1:380-389.

Booker SA, Domanski AP, Dando OR, Jackson AD, Isaac JT, Hardingham GE, Wyllie DJ, Kind PC (2019) Altered dendritic spine function and integration in a mouse model of fragile X syndrome. Nat Commun 10:4813.

Carcea I, Patil SB, Robison AJ, Mesias R, Huntsman MM, Froemke RC, Buxbaum JD, Huntley GW, Benson DL (2014) Maturation of cortical circuits requires Semaphorin 7A. Proc Natl Acad Sci USA 111:1397813983.

Cases O, Vitalis T, Seif I, De Maeyer E, Sotelo C, Gaspar P (1996) Lack of barrels in the somatosensory cortex of monoamine oxidase A-deficient mice: role of a serotonin excess during the critical period. Neuron 16:297-307.

Catalano SM, Robertson RT, Killackey HP (1996) Individual axon morphology and thalamocortical topography in developing rat somatosensory cortex. J Comp Neurol 367:36-53.

Celikel T, Szostak VA, Feldman DE (2004) Modulation of spike timing by sensory deprivation during induction of cortical map plasticity. Nat Neurosci 7:534-541.

Cohen-Tannoudji M, Babinet C, Wassef M (1994) Early determination of a mouse somatosensory cortex marker. Nature 368:460-463.

Cooper NG, Steindler DA (1986) Lectins demarcate the barrel subfield in the somatosensory cortex of the early postnatal mouse. J Comp Neurol 249:157-169.

Crair MC, Malenka RC (1995) A critical period for long-term potentiation at thalamocortical synapses. Nature 375:325-328.

Cronk KM, Wilkinson GA, Grimes R, Wheeler EF, Jhaveri S, Fundin BT, Silos-Santiago I, Tessarollo L, Reichardt LF, Rice FL (2002) Diverse dependencies of developing Merkel innervation on the trkA and both full-length and truncated isoforms of trkC. Development 129:3739-3750.

Crouzin N, Baranger K, Cavalier M, Marchalant Y, Cohen-Solal C, Roman FS, Khrestchatisky M, Rivera S, Féron F, Vignes M (2013) Area-specific alterations of synaptic plasticity in the 5XFAD mouse model of Alzheimer's disease: dissociation between somatosensory cortex and hippocampus. PLoS One 8:e74667.

D’Amato RJ, Blue ME, Largent BL, Lynch DR, Ledbetter DJ, Molliver ME, Snyder SH (1987) Ontogeny of the serotonergic projection to rat neocortex: transient expression of a dense innervation to primary sensory areas. Proc Natl Acad Sci USA 84:4322-4326.

Datwani A, Iwasato T, Itohara S, Erzurumlu RS (2002a) Lesion-induced thalamocortical axonal plasticity in the S1 cortex is independent of NMDA receptor function in excitatory cortical neurons. J Neurosci 22:91719175.

Datwani A, Iwasato T, Itohara S, Erzurumlu RS (2002b) NMDA receptor-dependent pattern transfer from afferents to postsynaptic cells and dendritic differentiation in the barrel cortex. Mol Cell Neurosci 21:477-492.

Daw MI, Bannister NV, Isaac JT (2006) Rapid, activity-dependent plasticity in timing precision in neonatal barrel cortex. J Neurosci 26:4178-4187.

de Nó RL (1922) La corteza cerebral del ratón. Trabajos del Laboratorio de Investigaciones Biológicas de la Universidad de Madrid 20:41-78.

Diamond ME, Huang W, Ebner FF (1994) Laminar comparison of somatosensory cortical plasticity. J Neurosci 14:6978-6991.

Domanski AP, Booker SA, Wyllie DJ, Isaac JT, Kind PC (2019) Cellular and synaptic phenotypes lead to disrupted information processing in Fmr1KO mouse layer 4 barrel cortex. Nat Commun 10:4814

Durham D, Woolsey TA (1984) Effects of neonatal whisker lesions on mouse central trigeminal pathways. J Comp Neurol 223:424-447.

Ebara S, Kumamoto K, Matsuura T, Mazurkiewicz JE, Rice FL (2002) Similarities and differences in the innervation of mystacial vibrissal follicle-sinus complexes in the rat and cat: a confocal microscopic study. J Comp Neurol 449:103-119.

Egger R, Narayanan RT, Guest JM, Bast A, Udvary D, Messore LF, Das S, de Kock CP, Oberlaender M (2020) Cortical output is gated by horizontally projecting neurons in the deep layers. Neuron 105:122-137.e8.
Erzurumlu RS, Gaspar P (2012) Development and critical-period plasticity of the barrel cortex. Eur J Neurosci 35:1540-1553.

Erzurumlu RS, Jhaveri S (1990) Thalamic axons confer a blueprint of the sensory periphery onto the developing rat somatosensory cortex. Dev Brain Res 56:229-234.

Erzurumlu RS, Jhaveri S (1992) Emergence of connectivity in the embryonic rat parietal cortex. Cereb Cortex 2:336-352.

Erzurumlu RS, Killackey HP (1979) Efferent connections of the brainstem trigeminal complex with the facial nucleus of the rat. J Comp Neurol 188:75-86.

Erzurumlu RS, Killackey HP (1980) Diencephalic projections of the subnucleus interpolaris of the brainstem trigeminal complex in the rat. Neuroscience 5:1891-1901.

Erzurumlu RS, Killackey HP (1982a) Order in the developing rat trigeminal nerve. Brain Res 255:305-310.

Erzurumlu RS, Killackey HP (1982b) Critical and sensitive periods in neurobiology. In: Current topics in developmental biology (Moscona AA, Monroy A, eds), pp 207-240. San Diego: Academic.

Erzurumlu RS, Killackey HP (1983) Development of order in the rat trigeminal system. J Comp Neurol 213:365-380.

Espinosa JS, Wheeler DG, Tsien RW, Luo L (2009) Uncoupling dendrite growth and patterning: single-cell knockout analysis of NMDA receptor 2B. Neuron 62:205-217.

Fox K (1992) A critical period for experience-dependent synaptic plasticity in rat barrel cortex. J Neurosci 12:1826-1838.

Fox K (2002) Anatomical pathways and molecular mechanisms for plasticity in the barrel cortex. Neuroscience 111:799-814.

Frangeul L, Pouchelon G, Telley L, Lefort S, Luscher C, Jabaudon D (2016) A cross-modal genetic framework for the development and plasticity of sensory pathways. Nature 538:96-98.

Frost DO, Boire D, Gingras G, Ptito M (2000) Surgically created neural pathways mediate visual pattern discrimination. Proc Natl Acad Sci USA 97:11068-11073.

Fukuchi-Shimogori T, Grove EA (2001) Neocortex patterning by the secreted signaling molecule FGF8. Science 294:1071-1074

Gao WJ, Pallas SL (1999) Cross-modal reorganization of horizontal connectivity in auditory cortex without altering thalamocortical projections. J Neurosci 19:7940-7950

Gaspar P, Renier N (2018) Constraints on somatosensory map development: mutants lead the way. Curr Opin Neurobiol 53:43-49.

Gheorghita F, Kraftsik R, Dubois R, Welker E (2006) Structural basis for map formation in the thalamocortical pathway of the barrelless mouse. J Neurosci 26:10057-10067.

Gitton Y, Cohen-Tannoudji M, Wassef M (1999) Role of thalamic axons in the expression of $\mathrm{H}-2 \mathrm{Z1}$, a mouse somatosensory cortex specific marker. Cereb Cortex 9:611-620.

Godement P, Vanselow J, Thanos S, Bonhoeffer F (1987) A study in developing visual systems with a new method of staining neurones and their processes in fixed tissue. Development 101:697-713.

Govidan S, Jabaudon D (2017) Coupling progenitor and neuronal diversity in the developing neocortex. FEBS Lett 591:3960-3977.

Greig LC, Woodworth MB, Galazo MJ, Padmanabhan H, Macklis JD (2013) Molecular logic of neocortical projection neuron specification, development and diversity. Nat Rev Neurosci 14:755-769.

Greig LC, Woodworth MB, Greppi C, Macklis JD (2016) Ctip1 controls acquisition of sensory area identity and establishment of sensory input fields in the developing neocortex. Neuron 90:261-277.

Guy J, Staiger JF (2017) The functioning of a cortex without layers. Front Neuroanat 11:54

Hoerder-Suabedissen A, Molnár Z (2015) Development, evolution and pathology of neocortical subplate neurons. Nat Rev Neurosci 16:133-146.

Itami C, Kimura F (2012) Developmental switch in spike timing-dependent plasticity at layers 4-2/3 in the rodent barrel cortex. J Neurosci 32:1500015011 .

Itami C, Huang JY, Yamasaki M, Watanabe M, Lu HC, Kimura F (2016) Developmental switch in spike timing-dependent plasticity and cannabinoid-dependent reorganization of the thalamocortical projection in the barrel cortex. J Neurosci 36:7039-7054

Iwasato T, Erzurumlu RS (2018) Development of tactile sensory circuitry in the CNS. Curr Opin Neurobiol 53:66-75.

Iwasato T, Datwani A, Wolf AM, Nishiyama H, Taguchi Y, Tonegawa S, Knöpfel T, Erzurumlu RS, Itohara S (2000) Cortex-restricted disruption 
of NMDAR1 impairs neuronal patterns in the barrel cortex. Nature 406:726-731.

Iwasato T, Inan M, Kanki H, Erzurumlu RS, Itohara S, Crair MC (2008) Cortical adenylyl cyclase 1 is required for thalamocortical synapse maturation and aspects of layer IV barrel development. J Neurosci 28:59315943.

Kageyama GH, Wong-Riley MT (1982) Histochemical localization of cytochrome oxidase in the hippocampus: correlation with specific neuronal types and afferent pathways. Neuroscience 7:2337-2361.

Kaiserman-Abramof IR, Graybiel AM, Nauta WJ (1980) The thalamic projection to cortical area 17 in a congenitally anophthalmic mouse strain. Neuroscience 5:41-52.

Kanold PO, Luhmann HJ (2010) The subplate and early cortical circuits. Annu Rev Neurosci 33:23-48.

Khazipov R, Sirota A, Leinekuge X, Holmes GL, Ben-Ari Y, Buzsáki G (2004) Early motor activity drives spindle bursts in the developing somatosensory cortex. Nature 432:758-761.

Killackey HP (1973) Anatomical evidence for cortical subdivisions based on vertically discrete thalamic projections from the ventral posterior nucleus to cortical barrels in the rat. Brain Res 51:326-331.

Killackey HP, Belford GR (1979) The formation of afferent patterns in the somatosensory cortex of the neonatal rat. J Comp Neurol 183:305-321.

Killackey HP, Ebner FF (1972) Two different types of thalamocortical projections to a single cortical area in mammals. Brain Behav Evol 6:141-169.

Killackey HP, Ebner FF (1973) Convergent projection of three separate thalamic nuclei on to a single cortical area. Science 179:283-285.

Killackey HP, Leshin S (1975) The organization of specific thalamocortical projections to the posteromedial barrel subfield of the rat somatic sensory cortex. Brain Res 86:469-472.

Kivrak BG, Erzurumlu RS (2013) Development of the principal nucleus trigeminal lemniscal projections in the mouse. J Comp Neurol 521:299311.

Kole K, Scheenen W, Tiesinga P, Celikel T (2018) Cellular diversity of the somatosensory cortical map plasticity. Neurosci Biobehav Rev 84:100115

Kristt DA (1979) Somatosensory cortex: acetylcholinesterase staining of barrel neuropil in the rat. Neurosci Lett 12:177-182.

Land PW, Simons DJ (1985) Metabolic activity in SmI cortical barrels of adult rats is dependent on patterned sensory stimulation of the mystacial vibrissae. Brain Res 341:189-194.

Laurent A, Goaillard JM, Cases O, Lebrand C, Gaspar P, Ropert N (2002) Activity-dependent presynaptic effect of serotonin $1 \mathrm{~B}$ receptors on the somatosensory thalamocortical transmission in neonatal mice. J Neurosci 22:886-900.

Lebrand C, Cases O, Adelbrecht C, Doye A, Alvarez C, El Mestikawy S, Seif I, Gaspar P (1996) Transient uptake and storage of serotonin in developing thalamic neurons. Neuron 17:823-835.

Lebrand C, Cases O, Wehrlé R, Blakely RD, Edwards RH, Gaspar P (1998) Transient developmental expression of monoamine transporters in the rodent forebrain. J Comp Neurol 401:506-524.

Lee LJ, Iwasato T, Itohara S, Erzurumlu RS (2005) Exuberant thalamocortical axon arborization in cortex-specific NMDAR1 knockout mice. J Comp Neurol 485:280-292.

Lee LJ, Tsytsarev V, Erzurumlu RS (2017) Structural and functional differences in the barrel cortex of Mecp2 null mice. J Comp Neurol 525:39513961.

Li H, Fertuzinhos S, Mohns E, Hnasko TS, Verhage M, Edwards R, Sestan N, Crair MC (2013) Laminar and columnar development of barrel cortex relies on thalamocortical neurotransmission. Neuron 79:970-986.

Lieske V, Bennett-Clarke CA, Rhoades RW (1999) Effects of serotonin on neurite outgrowth from thalamic neurons in vitro. Neuroscience 90:967974.

Liguz-Lecznar M, Skangiel-Kramska J (2007) Vesicular glutamate transporters VGLUT1 and VGLUT2 in the developing mouse barrel cortex. Int J Dev Neurosci 25:107-114

Liu XB, Murray KD, Jones EG (2004) Switching of NMDA receptor 2A and $2 \mathrm{~B}$ subunits at thalamic and cortical synapses during early postnatal development. J Neurosci 24:8885-8895.

Lo FS, Erzurumlu RS (2018) Insulin receptor sensitization restores neocortical excitation/inhibition balance in a mouse model of autism. Mol Autism 9:13.
Lo FS, Zhao S (2011) N-methyl-D-aspartate receptor subunit composition in the rat trigeminal principal nucleus remains constant during postnatal development and following neonatal denervation. Neuroscience 178: 240-249.

Lo FS, Blue ME, Erzurumlu RS (2016a) Enhancement of postsynaptic GABAA and extrasynaptic NMDA receptor-mediated responses in the barrel cortex of Mecp2-null mice. J Neurophysiol 115:1298-3106.

Lo FS, Erzurumlu RS, Powell EM (2016b) Insulin-independent GABAA receptor-mediated response in the barrel cortex of mice with impaired Met activity. J Neurosci 36:3691-3697.

Lokmane L, Proville R, Narboux-Nême N, Györy I, Keita M, Mailhes C, Léna C, Gaspar P, Grosschedl R, Garel S (2013) Sensory map transfer to the neocortex relies on pretarget ordering of thalamic axons. Curr Biol 23:810-816

López-Bendito G, Cautinat A, Sánchez JA, Bielle F, Flames N, Garratt AN, Talmage DA, Role LW, Charnay P, Marín O, Garel S (2006) Tangential neuronal migration controls axon guidance: a role for neuregulin-1 in thalamocortical axon navigation. Cell 125:127-142.

Lu HC, Gonzalez E, Crair MC (2001) Barrel cortex critical-period plasticity is independent of changes in NMDA receptor subunit composition. Neuron 32:619-634

Ma PM, Woolsey TA (1984) Cytoarchitectonic correlates of the vibrissae in the medullary trigeminal complex of the mouse. Brain Res 306:374-379.

Maatuf Y, Stern EA, Slovin H (2016) Abnormal population responses in the somatosensory cortex of Alzheimer's disease model mice. Sci Rep 6:24560.

Matsui A, Tran M, Yoshida AC, Kikuchi SS, Mami U, Ogawa M, Shimogori T (2013) BTBD3 controls dendrite orientation toward active axons in mammalian neocortex. Science 342:1114-1118.

Minlebaev M, Colonnese M, Tsintsadze T, Sirota A, Khazipov R (2011) Early $\gamma$ oscillations synchronize developing thalamus and cortex. Science 334:226-229.

Mitrukhina O, Suchkov D, Khazipov R, Minlebaev M (2015) Imprecise whisker map in the neonatal rat barrel cortex. Cereb Cortex 25:34583467.

Mizuno H, Luo W, Tarusawa E, Saito YM, Sato T, Yoshimura Y, Itohara S, Iwasato T (2014) NMDAR-regulated dynamics of layer 4 neuronal dendrites during thalamocortical reorganization in neonates. Neuron $82: 365-379$

Mizuno H, Ikezoe K, Nakazawa S, Sato T, Kitamura K, Iwasato T (2018) Patchwork-type spontaneous activity in neonatal barrel cortex layer 4 transmitted via thalamocortical projections. Cell Rep 22:123-135.

Molliver ME, Welker E, Clarke PG (1994) Hendrik Van der Loos (19291993). Trends Neurosci 17:93-94.

Molnár Z, Garel S, López-Bendito G, Maness P, Price DJ (2012) Mechanisms controlling the guidance of thalamocortical axons through the embryonic forebrain. Eur J Neurosci 35:1573-1585.

Moreno-Juan V, Filipchuk A, Antón-Bolaños N, Mezzera C, Gezelius H, Andrés B, Rodríguez-Malmierca L, Susín R, Schaad O, Iwasato T, Schüle R, Rutlin M, Nelson S, Ducret S, Valdeolmillos M, Rijli FM, LópezBendito G (2017) Prenatal thalamic waves regulate cortical area size prior to sensory processing. Nat Commun 8:14172.

Nahmani M, Erisir A (2005) VGluT2 immunochemistry identifies thalamocortical terminals in layer 4 of adult and developing visual cortex. J Comp Neurol 484:458-473.

Nakamura K, Watakabe A, Hioki H, Fujiyama F, Tanaka Y, Yamamori T, Kaneko T (2007) Transiently increased colocalization of vesicular glutamate transporters 1 and 2 at single axon terminals during postnatal development of mouse neocortex: a quantitative analysis with correlation coefficient. Eur J Neurosci 26:3054-3067.

Nakazawa S, Mizuno H, Iwasato T (2018) Differential dynamics of cortical neuron dendritic trees revealed by long-term in vivo imaging in neonates. Nat Commun 9:3106.

Narboux-Nême N, Evrard A, Ferezou I, Erzurumlu RS, Kaeser PS, Lainé J, Rossier J, Ropert N, Südhof TC, Gaspar P (2012) Neurotransmitter release at the thalamocortical synapse instructs barrel formation but not axon patterning in the somatosensory cortex. J Neurosci 32:61836196.

O’Leary DD (1989) Do cortical areas emerge from a protocortex? Trends Neurosci 12:400-406.

Petersen CC (2019) Sensorimotor processing in the rodent barrel cortex. Nat Rev Neurosci 20:533-546. 
Piñon MC, Jethwa A, Jacobs E, Campagnoni A, Molnár Z (2009) Dynamic integration of subplate neurons into the cortical barrel field circuitry during postnatal development in the Golli-tau-eGFP (GTE) mouse. J Physiol 587:1903-1915.

Pouchelon G, Gambino F, Bellone C, Telley L, Vitali I, Lüscher C, Holtmaat A, Jabaudon D (2014) Modality-specific thalamocortical inputs instruct the identity of postsynaptic L4 neurons. Nature 511:471-474.

Rakic P (1988) Specification of cerebral cortical areas. Science 241:170-176.

Rakic P, Suñer I, Williams RW (1991) A novel cytoarchitectonioc area induced experimentally within the primate visual cortex. Proc Natl Acad Sci USA 88:2083-2087.

Rebsam A, Seif I, Gaspar P (2002) Refinement of thalamocortical arbors and emergence of barrel domains in the primary somatosensory cortex: a study of normal and monoamine oxidase a knock-out mice. J Neurosci 22:8541-8552

Rebsam A, Seif I, Gaspar P (2005) Dissociating barrel development and lesion-induced plasticity in the mouse somatosensory cortex. J Neurosci 25:706-710.

Renier N, Dominici C, Erzurumlu RS, Kratochwil CF, Rijli FM, Gaspar P, Chédotal A (2017) A mutant with bilateral whisker to barrel inputs unveils somatosensory mapping rules in the cerebral cortex. eLife 6: e23494.

Rhoades RW, Bennett-Clarke CA, Chiaia NL, White FA, Macdonald GJ, Haring JH, Jacquin MF (1990) Development and lesion induced reorganization of the cortical representation of the rat's body surface as revealed by immunocytochemistry for serotonin. J Comp Neurol 293: 190-207.

Rhoades RW, Bennett-Clarke CA, Shi MY, Mooney RD (1994) Effects of 5HT on thalamocortical synaptic transmission in the developing rat. J Neurophysiol 72:2438-2450.

Rice FL (1985a) Gradual changes in the structure of the barrels during maturation of the primary somatosensory cortex in the rat. J Comp Neurol 236:496-503.

Rice FL (1985b) An attempt to find vibrissa-related barrels in the primary somatosensory cortex of the cat. Neurosci Lett 53:169-172.

Rice FL, Van der Loos H (1977) Development of the barrels and barrel field in the somatosensory cortex of the mouse. J Comp Neurol 171:545560

Rice FL, Gomez C, Barstow C, Burnet A, Sands P (1985) A comparative analysis of the development of the primary somatosensory cortex: interspecies similarities during barrel and laminar development. J Comp Neurol 236:477-495.

Rice FL, Fundin BT, Arvidsson J, Aldskogius H, Johansson O (1997) Comprehensive immunofluorescence and lectin binding analysis of vibrissal follicle sinus complex innervation in the mystacial pad of the rat. J Comp Neurol 385:149-184.

Rose M (1929) Cytoarchitektonischer Atlas der Grosshirnrinde der Maus. J Psychol Neurol (Leipzig) 40:1-51.

Salichon N, Gaspar P, Upton AL, Picaud S, Hanoun N, Hamon M, De Maeyer E, Murphy DL, Mossner R, Lesch KP, Hen R, Seif I (2001) Excessive activation of serotonin (5-HT) $1 \mathrm{~B}$ receptors disrupts the formation of sensory maps in monoamine oxidase a and 5-HT transporter knock-out mice. J Neurosci 21:884-896.

Sauer B, Henderson N (1988) Site-specific DNA recombination in mammalian cells by the Cre recombinase of bacteriophage P1. Proc Natl Acad Sci USA 85:5166-5170.

Schlaggar BL, O'Leary DD (1991) Potential of visual cortex to develop an array of functional units unique to somatosensory cortex. Science 252:1556-1560.

Schlaggar BL, O'Leary DD (1994) Early development of the somatotopic map and barrel patterning in rat somatosensory cortex. J Comp Neurol 346:80-96.

Schlaggar BL, Fox K, O’Leary DD (1993) Postsynaptic control of plasticity in developing somatosensory cortex. Nature 364:623-626.

Senft SL, Woolsey TA (1991) Growth of thalamic afferents into mouse barrel cortex. Cereb Cortex 1:308-335

Sharma J, Angelucci A, Sur M (2000) Induction of visual orientation modules in auditory cortex. Nature 404:841-847.

Shetty AS, Godbole G, Maheshwari U, Padmanabhan H, Chaudhary R, Muralidharan B, Hou PS, Monuki ES, Kuo HC, Rema V, Tole S (2013) Lhx2 regulates a cortex-specific mechanism for barrel formation. Proc Natl Acad Sci USA 110:E4913-E4921.
Simi A, Studer M (2018) Developmental genetic programs and activity-dependent mechanisms instruct neocortical area mapping. Curr Opin Neurobiol 53:96-102.

Steindler DA, Cooper NG, Faissner A, Schachner M (1989) Boundaries defined by adhesion molecules during development of the cerebral cortex: the J1/tenascin glycoprotein in the mouse somatosensory cortical barrel field. Dev Biol 131:243-260.

Stocker AM, O'Leary DD (2016) Emx1 is required for neocortical area patterning. PLoS One 11:e0149900.

Suzuki A, Lee LJ, Hayashi Y, Muglia L, Itohara S, Erzurumlu RS, Iwasato T (2015) Thalamic adenylyl cyclase 1 is required for barrel formation in the somatosensory cortex. Neuroscience 290:518-529.

Tiriac A, Uitermarkt BD, Fanning AS, Sokoloff G, Blumberg MS (2012) Rapid whisker movements in sleeping newborn rats. Curr Biol 22:2075-2080.

Toda T, Homma D, Tokuoka H, Hayakawa I, Sugimoto Y, Ichinose H, Kawasaki H (2013) Birth regulates the initiation of sensory map formation through serotonin signaling. Dev Cell 27:32-46.

Tolner EA, Sheikh A, Yukin AY, Kaila K, Kanold PO (2012) Subplate neurons promote spindle bursts and thalamocortical patterning in the neonatal rat somatosensory cortex. J Neurosci 32:692-702.

Trachtenberg JT, Chen BE, Knott GW, Feng G, Sanes JR, Welker E, Svoboda $\mathrm{K}$ (2002) Long-term in vivo imaging of experience-dependent synaptic plasticity in adult cortex. Nature 420:788-794.

Tsien JZ, Chen DF, Gerber D, Tom C, Mercer EH, Anderson DJ, Mayford M, Kandel ER, Tonegawa S (1996) Subregion- and cell type-restricted gene knockout in mouse brain. Cell 87:1317-1326.

Tsytsarev V, Arakawa H, Zhao S, Chédotal A, Erzurumlu RS (2017) Behavioral consequences of a bifacial map in the mouse somatosensory cortex. J Neurosci 37:7209-7218.

Uziel D, Mühlfriedel S, Bolz J (2008) Ephrin-A5 promotes the formation of terminal thalamocortical arbors. Neuroreport 19:877-881.

Van der Loos H (1976) Barreloids in mouse somatosensory thalamus. Neurosci Lett 2:1-6.

Van der Loos H, Woolsey TA (1973) Somatosensory cortex: structural alterations following early injury to sense organs. Science 179:395-398.

Van der Loos H, Welker E, Dörfl J, Rumo G (1986) Selective breeding for variations in patterns of mystacial vibrissae of mice: bilaterally symmetrical strains derived from ICR stock. J Hered 77:66-82.

Vitalis T, Dauphinot L, Gressens P, Potier MC, Mariani J, Gaspar P (2018) $\operatorname{ROR} \alpha$ coordinates thalamic and cortical maturation to instruct barrel cortex development. Cereb Cortex 28:3994- 4007.

Vue TY, Lee M, Tan YE, Werkhoven Z, Wang L, Nakagawa Y (2013) Thalamic control of neocortical area formation in mice. JNeurosci33:8442-8453.

Wallace H, Fox K (1999) Local cortical interactions determine the form of cortical plasticity. J Neurobiol 41:58-63.

Wang CF, Hsing HW, Zhuang ZH, Wen MH, Chang WJ, Briz CG, Nieto M, Shyu BC, Chou SJ (2017) Lhx2 expression in postmitotic cortical neurons initiates assembly of the thalamocortical somatosensory circuit. Cell Rep 18:849-856.

Welker E, Van der Loos H (1986) Quantitative correlation between barrelfield size and the sensory innervation of the whiskerpad: a comparative study in six strains of mice bred for different patterns of mystacial vibrissae. J Neurosci 6:3355-3373.

Welker E, Armstrong-James M, Bronchti G, Ourednik W, GheorghitaBaechler F, Dubois R, Guernsey DL, Van der Loos H, Neumann PE (1996) Altered sensory processing in the somatosensory cortex of the mouse mutant barrelless. Science 271:1864-1867.

Wiesel TN, Hubel DH (1963) Single cell responses in striate cortex of kittens deprived of vision in one eye. J Neurophysiol 26:1003-1017.

Wong-Riley M (1979) Changes in the visual system of monocularly sutured or enucleated cats demonstrable with cytochrome oxidase histochemistry. Brain Res 171:11-28.

Wong-Riley MT, Welt C (1980) Histochemical changes in cytochrome oxidase of cortical barrels after vibrissal removal in neonatal and adult mice. Proc Natl Acad Sci USA 77:2333-2337.

Wong-Riley MT, Merzenich MM, Leake PA (1978) Changes in endogenous enzymatic reactivity to $\mathrm{DAB}$ induced by neuronal inactivity. Brain Res 141:185-192.

Woolsey CN (1952) Patterns of localization in sensory and motor cortex. In: The biology of mental health and disease: the Twenty-Seventh Annual Conference of the Milbank Memorial Fund, pp 193-205. New York: Harper. 
Woolsey TA (1967) Somatosensory, auditory and visual cortical areas of the mouse. Johns Hopkins Med J 121:91-112.

Woolsey TA (2016) Re: Woolsey TA, Van der Loos H. 1970. The structural organization of layer IV in the somatosensory region (SI) of mouse cerebral cortex: the description of a cortical field composed of discrete cytoarchitectonic units. Brain Res 17:205-242. Brain Res 1645:22-24.

Woolsey TA, Van der Loos H (1970) The structural organization of layer IV in the somatosensory region (SI) of mouse cerebral cortex: the description of a cortical field composed of discrete cytoarchitectonic units. Brain Res 17:205-242. [Erratum in: Brain Res (1970) 205-242].

Woolsey TA, Wann JR (1976) Areal changes in mouse cortical barrels following vibrissal damage at different postnatal ages. J Comp Neurol 170:5366

Woolsey TA, Anderson JR, Wann JR, Stanfield BB (1979) Effects of early vibrissae damage on neurons in the ventrobasal (VB) thalamus of the mouse. J Comp Neurol 184:363-380.
Yamashita T, Vavladeli A, Pala A, Galan K, Crochet S, Petersen SS, Petersen CC (2018) Diverse long-range axonal projections of excitatory layer $2 / 3$ neurons in mouse barrel cortex. Front Neuroanat 12:33.

Yang JW, Kilb W, Kirischuk S, Unichenko P, Stüttgen MC, Luhmann HJ (2018) Development of the whisker-to-barrel cortex system. Curr Opin Neurobiol 53:29-34.

Young-Davies CL, Bennett-Clarke CA, Lane RD, Rhoades RW (2000) Selective facilitation of the serotonin(1B) receptor causes disorganization of thalamic afferents and barrels in somatosensory cortex of rat. J Comp Neurol 425:130-138.

Zembrzycki A, Chou SJ, Ashery-Padan R, Stoykova A, O’Leary DD (2013) Sensory cortex limits cortical maps and drives top-down plasticity in thalamocortical circuits. Nat Neurosci 16:1060-1067.

Zembrzycki A, Perez-Garcia CG, Wang CF, Chou SJ, O’Leary DD (2015) Postmitotic regulation of sensory area patterning in the mammalian neocortex by Lhx2. Proc Natl Acad Sci USA 112:6736-6741. 